\title{
The Problematic of the Gradual Transition of Urban Spaces into "Non-Places: the Urban Squares of Antalya (Turkey)"
}

\author{
Sadik Gokhan Ekinci (Corresponding author) \\ Faculty of Architecture, Akdeniz University, PO box 07058, Antalya, Turkey \\ E-mail: ekinci@akdeniz.edu.tr \\ Kemal Reha Kavas \\ Faculty of Architecture, Akdeniz University, PO box 07058, Antalya, Turkey \\ E-mail: kemalkavas@akdeniz.edu.tr
}

\begin{abstract}
During the $20^{\text {th }}$ century, where modernist design approaches had been determining factors, the concept of "place" had a significant place in the literature of architecture and urban design. For this reason, this concept, which has been elaborated by philosophy, sociology, anthropology and ethnography, has also been important from the viewpoints of architecture and the city. The definition of "place" has represented characteristics specific to a certain location on the globe, therefore it has been a requisite for the sense of spatial belonging. Whereas, the objectives of the industrial revolution and modernism, which are oriented towards mass production and standardization, have validated the independence of the individuals and processes of spatial production from the specificities of place. These changes led to the emergence of the concept of "non-place." This new concept, which should be interpreted as the antonym of place, signify spaces which are dissociated from the geographical, climatic and cultural characteristics of place by destroying the sense of spatial belonging. Airports and shopping malls may be considered as examples. Today, it is observed that individuals are gradually distancing themselves from urban spaces by being attracted by special areas with the procedures of security. It can be argued that urban squares, which no longer produce social and spatial belonging and which are used by less people, have been transformed into "non-places". Some of these spaces may lose the character of "place," which they possess historically, and some may be devoid of the conception of place starting from their design till their use. During the transition of urban spaces into non-places, problems of design and loss of the sense of belonging play significant roles. This study analyses the above-mentioned problems by comparing the selected urban squares at the city center of Antalya. In this framework analyses are made with respect to the human and urban scales. The study unfolds and interprets the negative and positive aspects regarding the production of the characteristics of "place".
\end{abstract}

Keywords: City, square, place, non-place, modernism, Antalya.

DOI: $10.7176 / J S T R / 5-12-29$

\section{Kentsel Mekanların Zamanla "Yok-Yerlere" Dönüşmesi Sorunsalı: Antalya Kent Meydanları}

Özet

Modernist tasarım yaklaşımlarının belirleyici olduğu 20. Yüzyıl boyunca mimari ve kentsel tasarım bağlamlarında "yer" kavramı literatürde önemli bir yer edinmiştir. Bu sebeple felsefe, sosyoloji, antropoloji, etnografya gibi disiplinlerin ilgilendiği kavram mimarlık ve kent açısından da önem kazanmıştır. "Yer", dünya üzerinde belirli bir konuma özgü karakteri temsil edici şekilde tanımlanmış, bu sebeple mekânsal aidiyetin de koşulu haline gelmiştir. Buna karşın sanayi devrimi ve modernizmin seri üretim ve standardizasyona yönelik hedefleri bireylerin ve mekânsal üretim süreçlerinin yerden 
bağımsızlaşmasını olumlu bir özellik olarak görmüştür. Bu değişimler "yok-yer” kavramının ortaya atılmasına sebep olmuştur. Yer'in karşıtı olarak yorumlanmaması gereken "yok-yer” yere özgü coğrafi, iklimsel, kültürel verilerden bağımsızlaşarak mekânsal aidiyet duygusunu ortadan kaldıran mekanlardır. Havalimanları ve alışveriş merkezleri örnek olarak verilebilir. Günümüzde bireylerin kentsel mekanlardan gittikçe uzaklaşıp kendileri için yapılmış özel ve güvenlikli alanlara yöneldikleri gözlenmektedir. Toplumsal ve mekânsal aidiyet üretmeyen ve kullanımları günümüzde gittikçe azalan kent meydanlarının da “yok-yer” özelliği gösterdiği düşünülebilir. Bu mekânların bazıları tarihsel olarak sahip oldukları "yer" karakterini yitirme sürecine girebilmekte, bazıları ise tasarım aşamasından kullanım aşamasına dek “yer” kavrayışından yoksun kalmaktadır. Kentsel meydanların yok-yere dönüşmelerinde tasarım sorunlarının yanı sıra aidiyet hissinin kaybı önemli rol oynamaktadır. Özetlenen sorunlar, bu çalışmada Antalya il merkezinden seçilen kentsel meydanların karşılaştırılması ile incelenmektedir. Bu çerçevede kent ve birey ölçeğinde analiz yapılarak "yer" karakterinin oluşumuna ilişkin olumlu ve olumsuz yönler tespit edilmekte ve değerlendirilmektedir.

Anahtar Sözcükler: Kent, meydan, yer, yok-yer, modernizm, Antalya.

\section{Giriş}

Yer kavramı, Türk Dil Kurumu'ndaki sözlük anlamıyla bir şeyin, bir kimsenin kapladığı veya kaplayabileceği boşluk, mahal, mekân anlamına gelmektedir. (https://sozluk.gov.tr/) 'Yer etmek', 'yersiz yurtsuz', 'yerini bulmak' gibi dilimize yerleşmiş anlamları olan yer kavramı, tarihsel süreçte felsefe, sosyoloji, antropoloji, etnografi, mimarlık vs. gibi disiplinler tarafindan farklı anlamlarda yeniden yorumlanmış olup bu gibi nedenlerle kesin bir tanımının yapılması zordur. Ancak, birçok disiplin 'yer' in tanımını yapmaya çalışmaktan geri kalmamıştır.

Aristoteles'e göre hayranlık uyandırıcı bir güce sahip olan; bir kap gibi düşünülebilecek, nesnelerin onsuz olamadığı; onun ise nesneler olmadan da olabileceği bir fiziksellikken, Heidegger'e göre yer, ikamet etme kavramı ile açıklanması gereken, felsefi bir kavramdır. (Sharr 2010) Casey'e göre, kendinden başka hiçbir şey tarafindan kuşatılamayacak olmasının sağladığı güçle, bir eşiktir ve var olan her şeyin durumudur. Olmak, yerde olmaktır. (Casey 1997) Norberg-Schulz ise bu konuda Heiddegger'i destekler: ikamet edildiği takdirde aidiyet duyulur. (Norberg-Schulz 1993) Yer ve yaşam birbirlerine aittir. Yer, yaşamı görünür kılan şeydir. Giddens'e göre ise, toplumsal yaşamın mekânsal boyutları, 'mevcudiyet' ile, yani yerel etkinlikle belirlenir. Ancak modernliğin ortaya çıkışı ile uzak (namevcut) kişiler arasındaki ilişkilerin gelişimi yerden kopuşa neden olur. (Giddens 2004)

Modernizmin sanayi devrimi sonrası bütün disiplinlerde yer etmesi, Giddens'in de söylediği gibi bireylerin yerden bağımsızlaşması, gelişen yeni teknolojilerle hızlı hareket edebilmeleri ile birlikte, mevcudiyet, ikamet terimlerinden zamanla uzaklaşarak başka bir şeye evrilmiştir. Marc Augé, anlamı değişime uğrayan 'yer 'i yeni bir kavram olarak ortaya koyduğu 'yok-yer' tanımlaması üzerinden yorumlar. Yer'in olumsuzu olarak yorumlanmaması gereken yok-yer, içinde bulunduğumuz dünyanın toplumsal ve mimari bir gerçekliği haline gelmiştir. Bu gerçeklik, mutlak yalnızlığın olduğu ya da kendiliğinden davranışları kodlayan hiçbir toplumsal ilişkiyi tarif etmeyen mekânlardır. Bu mekânlara örnek olarak havalimanları, alışveriş merkezleri, süpermarketler, geçiş mekânları, otobanlar vb. verilebilir. (Auge 2016)

Mutlak yalnızlığın olduğu mekânlar arasında kullanımları günümüzde gittikçe azalan ve yok-yerlere evrilen kentsel mekânlar dikkat çekmektedir. Kevin Lynch'e göre meydanlar, kentsel mekânlarda oluşturulmuş yoğun aktivite odaklarıdır (Lynch 2011). Norberg-Schulz, meydanı "kentsel yapının en belirgin ve göze çarpan unsuru" olarak tanımlamıştır; "Açıkça sınırları belirlenmiş bir yer olduğundan, zihinde canlandırılması, düşünülmesi en kolay olandır ve hareket için bir hedefi temsil eder" diye belirtmiştir. (Norberg-Schulz 1971) Christopher Alexander'a göre meydanlar; insanlar için bir tür yaşamı paylaşma şeklidir. Eğer meydan yeterli aktiviteyi barındırıyorsa, insanlar tarafindan fark edilecektir. Çünkü, bir meydanın canlılığına meydandaki insan sayısından çok, kullanıcı grubu için; mekânda iyi vakit geçirebilme, görsel kalite, konfor, fonksiyonların çeşitliliği, boş zamanlarını değerlendirebilecekleri ve sıkılmayacakları aktivitelerden oluşan alanların yer alması önemlidir. Böylece, kentsel yaşamın canlandırılması da söz konusu olacaktır. Bu canlanma ile birlikte kentsel anılar çoğalacak, aidiyet hissi kuvvetlenecek ve kentsel meydan bir "yer" olacaktır (Alexander 1977).

Günümüzde kentsel meydanların kullanılabilir yer olmaktan çıktıkları, önemli resmi gün ve haftalarda farkına varılan ve meydanı oluşturan temel ögelerden yoksun yok-yerlere dönüştükleri gözlemlenmektedir. Oysa kentsel bir meydan, fiziksel özelliklerinin yanısıra toplumsal, sosyolojik, psikolojik anlamlarıyla bir bütün olarak ele alınması gereken, kentsel yaşamın canlılığını ve mevcudiyet hissini içinde barındıran bir 'yer' olmalıdır. 


\section{Kavramsal Altyapı}

\section{1 "Yok-Yer" Kavramı}

Bir yandan yer kavramı üzerine düşünceler üretebilmek oldukça zor iken, diğer yandan bu üretimi gerçekleştirebilmek yok-yer kavramına referans vermeden imkansız hale gelmiştir. Yer kavramını tanımlamak, anlamak, onun üzerine ve onun aracıllğıyla düşünce üretmek için onun yalnızca fiziksel boyutunu analiz etmek yeterli değildir. Zihinsel, sezgisel, algısal, deneyime bağlı pratikleri de dâhil eden bakış açıları geliştirmek önemlidir. Bu bağlamda, Marc Augé'nin ortaya koyduğu "yok-yer", içinde bulunduğu kavram ailesine ufuk açıcı yenilikler getirmiştir.

Tarih boyunca "yer", ilgili metinlerde "mekân" ile ilişkilendirilerek geçmektedir. İki kavramın aynı, karşıt ve birbirini karşılayan kullanımlarına rastlamak mümkündür (Ötkünç 2016). Antik metinlerden aydınlanmaya kadar yer kavramı kullanılmış, Rönesans sonrası ise mekân kavramı daha sık kullanılmaya başlanmıştır. Modernizm sonrası, iki kavram birbirinden daha belirgin ayrışmaya başlamıştır. Yerin en çok tartışılan ve anlamlandırılan vasfı olan kimlik oluşturma ve aidiyet hissi üzerinden yer yeniden yorumlanmış ve mekândan bu bağlamda ayrışmıştır. Marc Augé'nin 'süpermodernizm', 'ikinci modernizm', veya 'üstmodernizm' olarak adlandırdığı modernizm sonrası dönemi, bireyin yere bağımlılığının giderek azalmasından oluşan kimliksizlik sonucu oluşan yok-yer kavramıyla incelenmektedir. (Auge 2016)

Augé'ye göre, bir alanın antropolojik olarak 'yer' haline gelebilmesi için, orada insanlar arasında tekrarlanan karşılaşmaların olması, oranın karmaşık bağlantılar yoluyla zihnimizde oluşması gerekmektedir. Antropolojik yer, orada yaşayanlar için anlam taşır. Yok-yer ise, bireyi kimliğinden uzaklaştıran, anonimleştiren bir yaklaşımdır. Birey, yerde kendine ait hatıralar bulurken ve aidiyet hissederken; yok-yerde hiçbir ilişki geliştirmeden anonimleşir. Örneğin : 'Bir havalimanında 50.000 kişi olabilir; ancak birbirleriyle hiçbir ilişki geliştirmek zorunda değildirler. Dört kasabaya aynı uzaklıkta konumlanmış bir süpermarket mükemmel bir yok-yerdir; ancak kasabanın gençleri orada buluşup orayı bir yer haline getirebilirler' ve bu bağlamda; yer bireyin deneyimine bağlı olarak yer olma özelliği gösterir ve yok-yer'in zıttı değildir. (Auge 2016) Yok-yer üzerinden yeniden yorumlanan yer, adeta insanın yer ile olan ilişkisini çağdaş dünyanın gerçekliğine göre tekrar kavramsallaştırmaktadır.

\subsection{Kent Meydanı Tanımı ve Mekansal Gelişimi}

Meydan; Latincede açık yer ya da genişletilmiş cadde anlamına gelen "Platea", İngilizce ve Fransızcada "Place" kelimesinden doğmuştur. İspanyolca "Plaza" ve İtalyanca "Piazza" da aynı kökenden gelmektedir (Marcus ve Francis 1998). Genel anlamı ile meydan; insanın eylemlerini yerine getirdiği, onu kuşatan, bütünleşme ve sahip olma duygusunu yaratan, yatay ve düşey hacimsel elemanlarla sınırlanmış üç boyutlu hacimsel bir düzenlemedir (Öztan 1998).

Kabile şefinin bulunduğu yerin etrafinda yer almış olan ilkel bir yaşam, kentlerin ilk gelişmelerinde bir odak yeri ya da yol güzergahlarında ve kavşaklarda gelişen ekonomik yaşamla gelişen meydan; zaman zaman savaş tehlikeleri ile toplumları içe dönük bir düzen ve belirli bir merkez etrafinda toplanmaya yöneltmiştir. Daha sonraları gittikçe gelişerek saray, mabet-meydan kompleksini kuşatan yerleşme üniteleri şekline girmişlerdir. Mısır, Hitit, Yunan, Roma gibi ilkçağlardan başlayarak, Ortaçăg, Rönesans, Barok devirlerini de kapsayan 19.yüzyıla kadar olan zaman süresince, kentler bu ana fikirde gelişmişlerdir. 21. yüzyılda da meydan kavramı, zaman zaman temel işlevini yitirip, kimlik arayışı içerisine girerek, elindeki kimliğinin aşınıma uğramasına neden olmuştur.

İnsanlar toplanma ve bir arada bulunma isteği doğrultusunda kentlerde açık veya kapalı mekânlar oluşturmuşlardır. Her kentin düzenli bir şekilde ortak yaşamının geçtiği kentsel mekânları vardır. $\mathrm{Bu}$ mekânlar, kentte önemli fonksiyonlara sahiptir. Meydan biçiminde ortaya çıkan ilk kentsel açık mekânlar, kentin kültürünü yansıtmakta olup geçmişle gelecek arasında bağlantı kuran kültürel ortamlardır. Tarihi kent meydanları, bulunduğu kent ve tarihte yaşanmış önemli olaylarla özdeşleşmiştir.

Meydanlar, her ülkenin hatta her kentin doğal, kültürel, sosyal ve ekonomik özelliklerine göre farklı içerik ve fonksiyonlara sahiptir. Sosyal, ekonomik ve kültürel değerlerde, nüfus ve teknolojide görülen değişimler kentsel mekânlara da yansımaktadır. Bunun sonucu olarak günümüzde meydanların konumu, fonksiyonel ve fiziksel özelliklerinin farklılaştığı gözlenmektedir. Kentlerde ilk olarak meydanlarda yaya mekânı oluşturulmuştur. Merkezi donatıların ve kullanımların yer aldığı kent merkezleri, mahalle merkezlerinden gelen yaya yollarının birleşmesiyle meydanları oluşturur. Yaya bölgesi olarak meydanlar, bütün kent halkının kullanımına açık mekânlardır.

Fauole, meydanı tasarlanmış çevreyle tanımlanmış boş mekânlar olarak tarif eder ve bir yerin meydan olarak tanımlanabilmesi için öncelikli olarak yayalaştırılması gerektiğini ifade eder. Bir meydanın tasarlanmasındaki temel kriter o meydanın yapıldığı yerin niteliğini arttırmasıdır.(Fauole 1995). Kevin Lynch'e göre meydanlar, kentsel mekânlarda oluşturulmuş yoğun aktivite odaklarıdır. Tipik olarak meydanlar döşenmiş, yüksek yoğunlukta yapılar ve caddelerle çevrelenmiştir. İnsan gruplarını 
etkileyecek ve buluşmaları kolaylaştıracak özellikler taşır. (Marcus ve Francis 1998).

Krier, tarihsel süreçte meydanlar kentsel açık mekân kullanımında meydan kavramı ilk çağlardan günümüze kadar süregeldiğini ve konut birimlerinin açık bir alan etrafında gruplandırılmasıyla ortaya çıktığını söyler. Bu düzenleme; içerisinde kalan alanın büyük ölçüde kontrolüne imkân vermesinin yanı sıra dış etkenlere karşı korumayı da kolaylaştırmıştır. Meydanlar; etrafındaki odaların tanımladığı merkezi avludan, revaklı camii ve manastır avlularına ya da daha büyük ölçekte agora ve forum örneklerine kadar uzanmıştır. (Krier 1976)

Kentlinin birbiriyle etkileşimde bulunarak sosyalleştiği kabul edilen kent meydanlarının tarihteki ilk örneklerine Çatalhöyük'te konut gruplarının aralarından kurgulanan avlular gösterilebilir (Şekil 1) (Aykurt, 2010: 3).

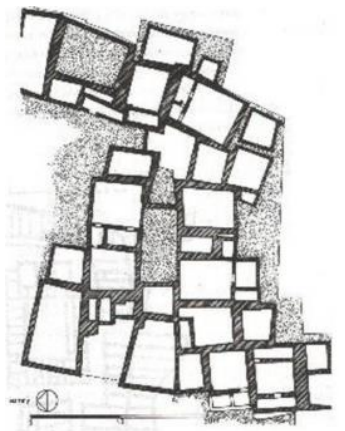

Şekil 1. Çatalhöyük’ te avlu etrafinda evlerin yerleşimi (Kuntay 1994)

Günümüz meydan tanımına ve kentteki kurgusuna daha yakın örnekler ise antik Yunan döneminde kamusal mekânları oluşturan agoralardır. Agora, Eski Yunan'da genellikle kamu yapıları ile çevrili, popüler veya politik toplantı yeri olarak kullanılan, seçim ve yargılama gibi önemli olayların da gerçekleştiği pazaryeri veya ortak meydan olarak tanımlanabilir (Şekil 2) (Uzun, 2006: 16).

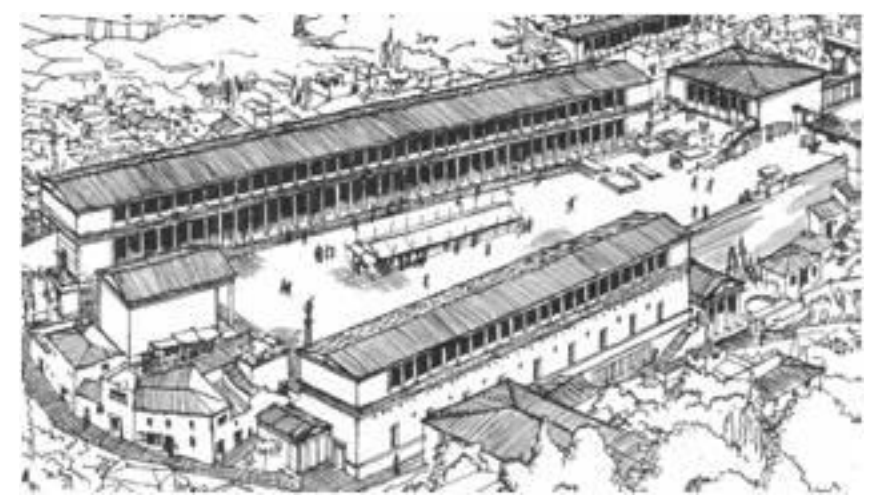

Şekil 2. Assos agorası (Uzun, 2006)

Roma döneminde meydan, Forum, sadece kullanıcı gereksinimi, bireysel ilişkiler ve ticaret gereksinimine yeterli olacak bir açık mekan olmaktan çok, kendisini çevreleyen binaların izlenmesi ve algılanmasına olanak sağlayacak bir ön mekan niteliğini ve fonksiyonunu da üstlenmiştir. Romalılar döneminde insan, meydanda anlam ve önem olarak arka planda yer almıştır. Önemli olan, meydan ve onu çevreleyen öğelerin mimari ve otorite değerlerinin vurgulanması olmuştur(Giritlioğlu 1991).

Öztan'a göre, kentlerin sosyal merkezler çevresinde konumlanması eski Türk yerleşimlerinde de görülmektedir. İlk İslam kentlerinde olduğu gibi önce dinsel kuruluşlar daha sonra kent oluşumu ilkesine yüzyıllar boyu uyularak cami bütün müştemilatı ile bir ticaret merkezi çevresinde biçimlendirilmişti. Osmanlı İmparatorluğu döneminde, büyük camiler çevrelerindeki çeşitli müştemilatı, medreseleri, avlusu ve ağaçlandırılmış mezarlığı ile bir mahallenin oluşumunu sağlamıştır. Camiyi çevreleyen avlunun halkın toplanma yeri olarak önemli bir fonksiyonu vardı. Osmanlı kentlerinde cami avluları bir bakıma kent meydanlarının yerini tutmaktaydı. Ayrıca büyük toplanma yerleri, çarşı ve pazar meydanlarıydı (Öztan 2008).

Meydanlar; 19. yüzyıla kadar uzun bir süre etraflarındaki mimari yapılarla kapalı formlardı. Özellikle 
modernizmle birlikte ortaya çıkan izole edilmiş bina formu ve tarihi meydanları oluşturan konutların banliyölere yayılmasıyla cephelerin sürekliliğini temel alan meydan formu değişmeye başlamıştır(Faoule 1995).

20. yüzyıl içinde kentlerdeki fonksiyonel değişimler, meydanların da değişik biçim ve fonksiyonlara cevap veren mekânlar olarak düzenlenmesine neden olmuştur. Böylece meydanlar; alış-veriş, oyun, toplantı, trafik, dini, ticaret vb. fonksiyonların gerçekleştirildiği açık ortak kullanım mekânları olarak tasarlanmıştır (Giritlioğlu 1991).

Günümüzde ise meydanlar, genellikle sert zeminli ve arabaların dışlandığ 1 halka açık mekânlar olarak tanımlanabilir. Meydanların en çok kullanım amaçları gezinmek, oturmak, yemek yemek ve izlemektir. (Marcus ve Francis 1998).

\section{3 “Yok-Yere” Evrilen Kent Meydanlart}

Genel anlamı ile insanın eylemlerini yerine getirdiği, onu kuşatan, bütünleşme ve sahip olma duygusunu yaratan, yatay ve düşey hacimsel elemanlarla sınırlanmış üç boyutlu hacimsel bir düzenleme olarak adlandırılan meydan, günümüz kentlerinde insan odaklı ve kimlik edinilen özelliklerini zamanla yitirmekte ve yer kavramından giderek uzaklaşmaktadır.

Meydanlar; insanlar için bir tür yaşamı paylaşma şeklidir. Eğer meydan yeterli aktiviteyi barındırıyorsa, insanlar tarafından fark edilecektir. Çünkü, bir meydanın canlılığına meydandaki insan sayısından çok, kullanıcı gurubu için; mekanda iyi vakit geçirebilme, görsel kalite, konfor, fonksiyonların çeşitliliği, boş zamanlarını değerlendirebilecekleri ve sıkılmayacakları aktivitelerden oluşan alanların yer alması önemlidir. Böylece, kentsel yaşamın canlandırılması da söz konusu olacaktır. Zucker’a göre; kent meydanları, tarih boyunca kentlerimizin kimliğini ve kişiliğini ortaya koyan önemli bir kentsel yaşam odağıdır. Çulcuoğlu'na göre tarihsel süreçte meydan şu şekilde aktarılmaktadır : "Meydanlar, bulundukları mekânın büyüklüğü, ya da gösterişliliği, formel ya da informel olması, sunduğu kullanım imkânlarına göre oluşturulduğu dönemdeki kültürü en iyi şekilde yansıtmaktadır. Bu nedenledir ki, Antik Yunan kentlerinde içinde çeşitli toplumsal konuların tartışıldığı agoralar, daha sade ve işlevsel yaşam tarzını, ortaçağda düzgün geometrik formlara sahip olmayan ancak birçok heykelin sergilendiği meydanlar, öncelikle yayalara hizmet veren, insanı ön plana çıkaran ve sanatsal yaşam tarzını, rönesansta denge unsurunun egemen olduğu meydanlar, şekilciliği temel alan yaşam tarzını, Barok dönemde hareketliliğin en iyi şekilde ortaya konduğu meydanlar, süslü ve gösterişli yaşam tarzını, modern dönemde artan iş yaşantısıyla birlikte artan araç trafiğine cevap veren, kent dokusu içinde sıkışıp kalmış durumda olan meydanlar ise daha mekanik bir yaşam tarzını ortaya koymaktadır."

Günümüz kentlerinde; kamusal binaların çevresi, buluşma yerleri, gösteriler için toplanma mekanları, tiyatro, sinema, restorant, cafe vb yerler, alış-veriş yapılan sokaklar, ofis gruplarının yer aldığı çevreler, konut alanlarında yer alan yarı özel mekanlar, trafik kavşakları ve daha pek çok dış mekanlara gereksinim vardır. $\mathrm{Bu}$ mekanların oluşturduğu meydanlar ise kentte birçok fonksiyonu gerçekleştirirler. $\mathrm{Bu}$ meydanlar sayesinde kentlerdeki bireyler, kendilerini daha fazla kente ait hissederler ve meydanları bir yer haline getirirler.

Türkiye'nin gelişme sürecinde yaşadığı hızlı kentleşme olgusuyla birlikte kentler sürekli büyümekte ve nitelik değiştirmektedir. Bu nedenle kent meydanları, tarih boyunca kentlerimizin kimliğini ortaya koyan önemli bir kentsel odak iken, günümüzde taşıt trafiğini hafifleten kavşak veya otopark olarak kullanılarak özgün değerlerini yitirme yolunda hızla ilerlemekte ve başka bir deyişle yok-yerlere evrilmektedirler. Bu sayede, bireyi kimliğinden uzaklaştırmakta ve anonimleştirmektedir. Tarihsel süreçte üstlendiği görevi devam ettirmesi beklenen ve aidiyet hissini vermesi beklenen kentsel meydanlar, bireylerle hiçbir ilişki geliştirmeyen anonimleştirici kentsel birer yok-yerlere evrilmiştir.

Kent meydanlarının yok-yerlere evrilmesi sorunsalını iyi analiz edebilmek için, problem kent ölçeğinde ve birey ölçeğinde olmak üzere iki ana başlıkta incelenmelidir. Kent ölçeği, kentsel meydanın kent ölçeğinde ve bireylerden bağımsız bir yer olma hali olarak tanımlanabilir. Bu durum, kentin bir bölgesinde yaşayan bireyin hiç deneyimlemediği ve aidiyet geliştirmediği bir diğer kentsel bölgeyi bir yeri tarif ederken kullanması örneğiyle açıklanabilir. Birey ölçeği ise, kentte yaşayan bireylerin biriktirdiği anılarla oluşturduğu aidiyet, anlamlandırma, kimlik gibi terimlerle açıklanabilir. Bu, çevresel estetik değerlerin yanısıra aidiyet hissi ile de ilişkilidir. Örneğin, bireyin yakın arkadaşıyla sürekli bir araya geldiği iyi tasarlanmış kentsel meydan, o birey için bir anlam taşımakta ve aidiyet hissini kuvvetlendirerek birey ölçeğinde bir yere dönüşmektedir. İki ana başlıkta incelenen kent ölçeği ve birey ölçeği, bir kentsel meydanda aynı anda olabileceği gibi, sadece birinin veya hiçbirinin olmadığ da gözlemlenebilir. Örneğin, bir kent meydanı, hem kentsel ölçekte hem birey ölçeğinde bir yer olabilmekte, sadece bireysel veya kentsel ölçekte bir yer olabilmekte veya her iki ölçekte de yer olamadığı tam yok-yer olarak da değerlendirilebilir. 


\section{Antalya Kent Meydanları İncelemeleri}

Antalya, Türkiye'nin güneybatısında yer alan, 1970 sonrası çevre illerden fazla miktarda göç almış olan bir turizm kentidir. Kontrolsüz gelen göç sonrası kent, hızla büyümeye başlamış ve tarihi kent duvarlarının sınırlarını aşarak kuzey, batı ve doğu yönlerinde hızla genişlemeye başlamıştır. Bu genişleme, kentte birçok değişiklikle beraber yeni kent meydanlarının da oluşmasına sebep olmuştur. Bu çalışmada, Antalya kent merkezinin ilk meydanı olan ve birey ölçeğinde ve kent ölçeğinde yer olabilme tanımını sağlayan Cumhuriyet Meydanı'nın yanı sıra bu iki ana başlığı farklı kombinasyonlarla sağlayan Kepez Kent Meydanı, Konyaaltı Kent Meydanı ve Muratpaşa Kent Meydanı da incelenmektedir.

\subsection{Cumhuriyet Meydanı}

Antalya kent merkezinin ilk meydanı olma özelliği taşıyan ve 11.500 metrekarelik alana sahip olan Cumhuriyet Meydanı, Kaleiçi surlarının hemen dışında konumlanır. Önceleri Mutassarıflık, sonraları Antalya Hükümet Konağı'nın (Şekil 3) burada yer alması, Antalya'da bütün resmi etkinliklerin bu cadde üzerindeki meydanda yapılmasına neden olmuş, dolayısıyla adı da Cumhuriyet Meydanı olarak değişmiştir (Aykurt, 2010: 38).

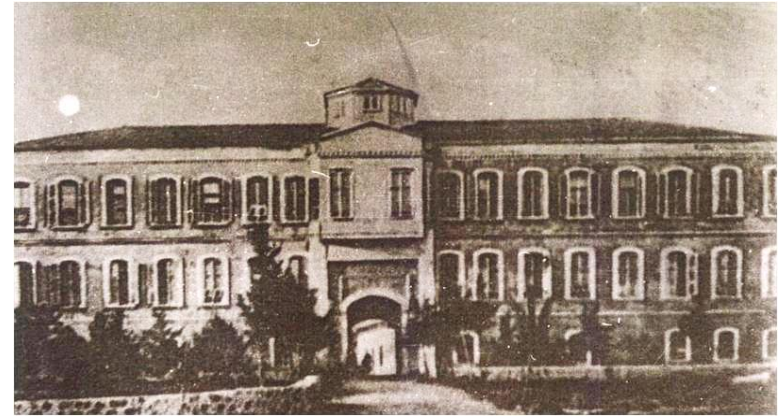

Şekil 3. Eski Hükümet Konağ1 (1920) (Aykurt,2010)

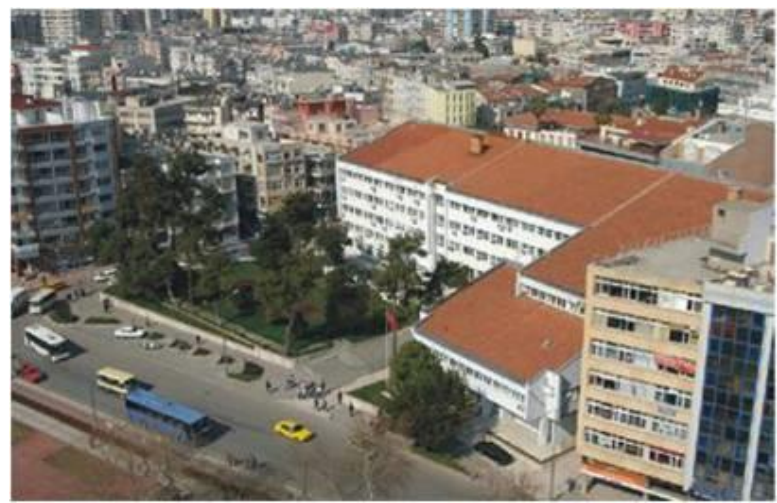

Şekil 4. 2008 senesinde yıkılan Hükümet Binası (Aykurt,2010)

Cumhuriyet Meydanı, Avrupa'daki meydan örnekleri ile bu bakımdan meydanın etrafindaki yönetim birimleri ile şekillenmesi benzer özellik taşır. Ancak meydanın şekillenmesine katkısı olan bu yapı (Şekil 3) maalesef günümüze ulaşmamıştır. Meydana kimliğini kazandıran, önemli bir sanatsal öğe olan 'Ulusal Yükseliş Anıtı' ise 1965 yılında yarışma projesi sonucu elde edilerek, meydana kazandırılmıştır (Aykurt 2010).

Meydan, eskiden kenti koruyan topların alanda bulunması nedeniyle Tophane Meydanı olarak isimlendirilmiştir. Yüzyılı aşkın bir süredir Mutasarrıflık, Hükümet Meydanı gibi yapıların alanda bulunması, resmi ve resmi olmayan bütün etkinliklerin meydanda yapılması sonucu adı Cumhuriyet Meydanı olarak değiştirilmiştir. Cumhuriyet Meydanı, kentin önemli geçiş noktalarından birisi olma özelliğini taşımakta ve şehrin merkezi konumunda bulunmaktadır. Ayrıca Cumhuriyet Meydanı etrafında çeşitli alışveriş ve iş merkezleri ile çeşitli kamu kurum ve kuruluşlarının bulunması ve tarihsel Kaleiçi yerleşiminin meydanın yakınında bulunması sebebiyle, meydan her mevsimde ve günün çeşitli saatlerinde yerel halk, yerli ve yabancı turistler tarafından yoğun bir şekilde kullanılmaktadır. Birçok kentsel aktiviteye ev sahipliği yapmakta olan meydan, farklı fonksiyonu içerisinde barındırması bakımından kent meydanı tanımını kentsel ölçekte sağlamaktadır. Bu bağlamda kolaylıkla Antalya kenti için kent ölçeğinde bir "yer" olarak değerlendirebilir. 


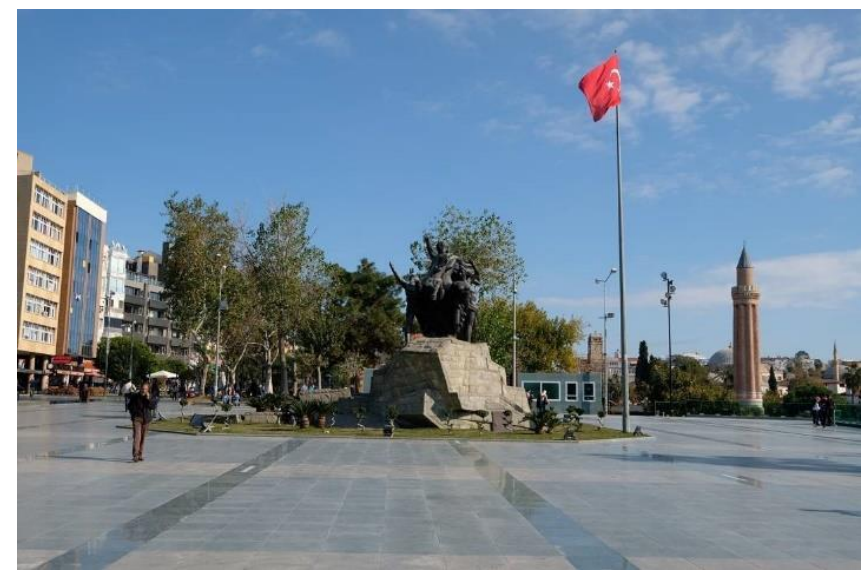

Şekil 5. Ulusal Yükseliş Anıtı

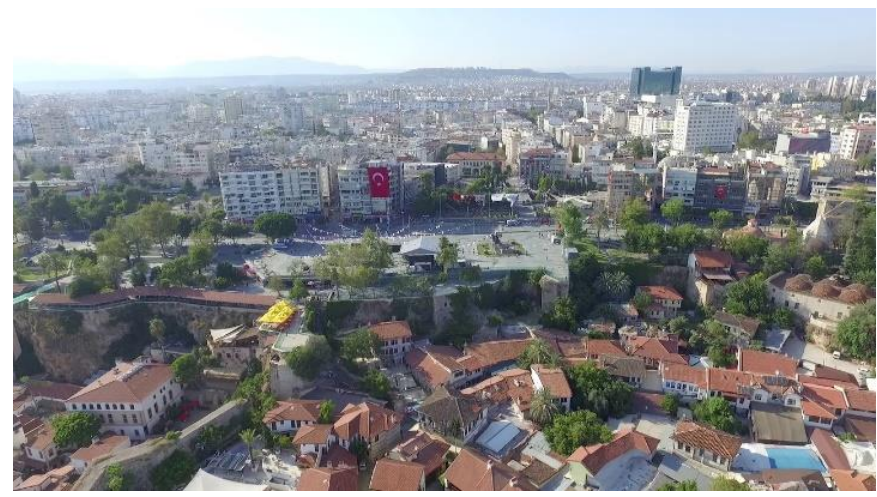

Şekil 6. Cumhuriyet Meydanı Hava Fotoğrafi

(Kaynak: https://www.youtube.com/watch?v=AynrRMCBuJI)

Hükümet binasının 2008'de yıkılmasından sonra yapılan ve günümüze ulaşan düzenlemede meydanda su elemanları (Şekil 7), oturma birimleri, yeşil alanlar, gölgeleme elemanları, seyir terasları gibi birimler bulunmakta, meydanın kuzey kısmının altında ise 2 katlı 14 araçlık büyük otobüs, 5 araçlık küçük otobüs ve 76 araçlık otomobil otoparkı bulunmaktadır. Meydan; çiçeklikler, banklar, alçak ve yüksek boylu aydınlatma direkleri, çöpler, sigaralıklar, döküm ağaç koruyucular ve membran gölgeleme alanları (Şekil 8) gibi estetik değeri olan donatılarla desteklenmektedir.

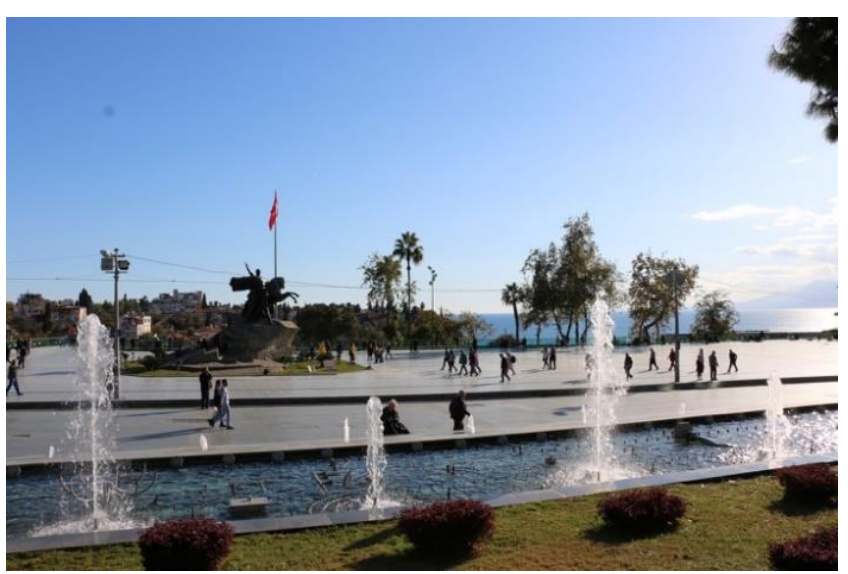

Şekil 7. Cumhuriyet Meydanı Havuz Alanı 


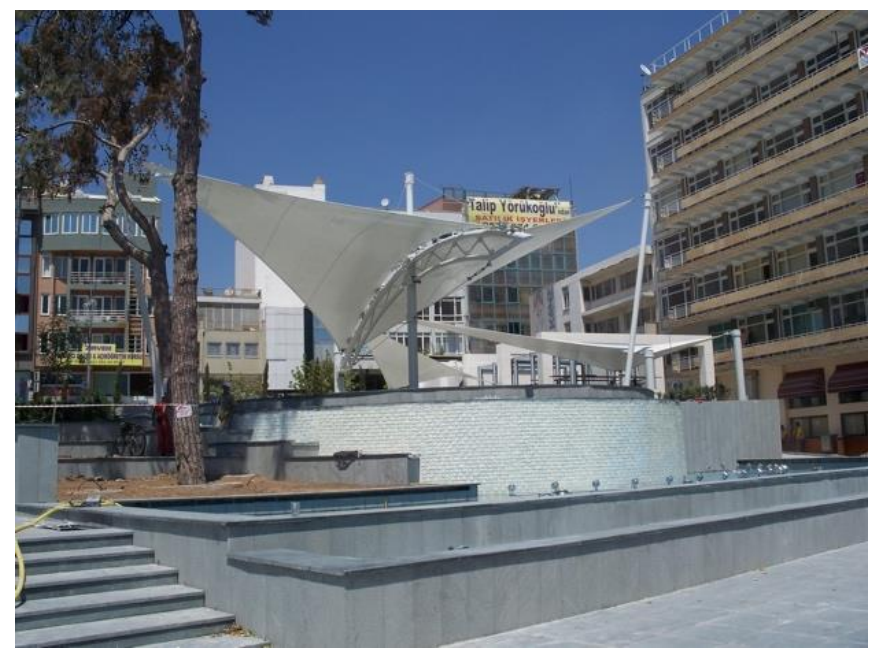

Şekil 8. Cumhuriyet Meydanı Gölgeleme Alanı

Cumhuriyet Meydanı, kent için ilk meydan olması özelliğinin yanısıra, her zaman simgesel özelliğini korumuştur. Kent ölçeğinde incelendiğinde 'yer' olan meydan, birey ölçeğinde de kentte yaşayan insanlara aidiyet hissi vermesi, estetik değeri olan çevresel donatılarla desteklenmesi ve kentliler için anlam taşıması bakımından da bir "yer" olarak değerlendirilebilir.

\subsection{Kepez Kent Meydanı}

Kepez, Antalya kent merkezinin kuzey çeperine yerleşmiş, 1970 sonrası Antalya'nın aldığı yoğun göç sorunuyla baş etmek zorunda kalmış, nüfus bakımından Antalya'nın en büyük ilçesi konumundadır. Bölge, sınırları bakımından hızlı göç sonucu plansız kentleşme sorunlarıyla karşı karşıya kalmış, bunun sonucu olarak kentsel gelişim bakımından kentin diğer bölgelerine kıyasla daha büyük zorluklar ve gecikmeler yaşamıştır. Bu tür gelişmeler sonucu, bölge sınırlarının kentsel planlamalar ve boşluklar bakımından zenginleşmesi günümüze kadar uzamıştır.

Yapım çalışmaları hala devam etmekte olan Kepez Kent Meydanı Projesi, kültürel, sanatsal, sosyal, sportif ve ticari faaliyetlerin yanı sıra peyzaj alanlarını da içinde barındırmayı hedeflemektedir. Kepez Kent Meydanı Projesi birinci kısım 54 bin metrekarelik, ikinci kısım tamamlanınca 166 bin metrekarelik bir alanı kapsamaktadır. Kepez'in coğrafi olarak merkezi olan Seyhan Caddesi'nde inşa edilen Kepez Kent Meydanı'nda çok amaçlı etkinlik alanı, rekreasyon, spor ve toplanma alanları, tören alanı, anıt alanı, ticari birimler, kamusal alanlar yer almaktadır.

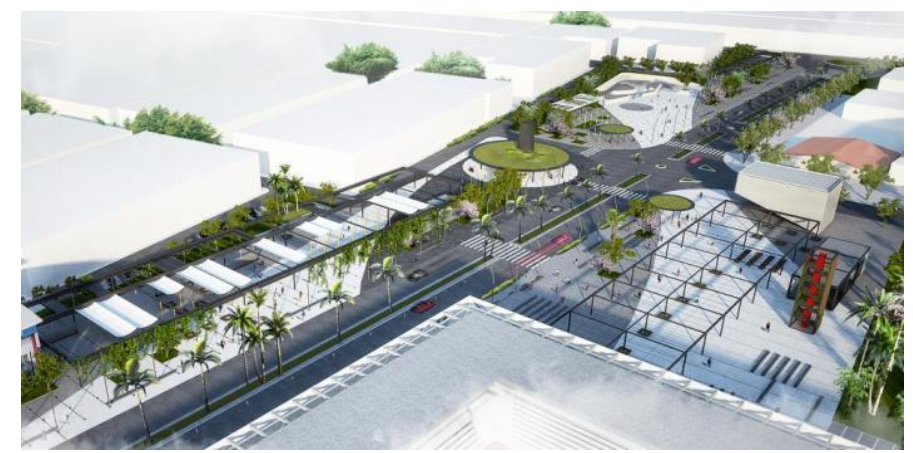

Şekil 9. Kepez Kent Meydanı (https://www.kepez-bld.gov.tr/news.php?id=6202/Kepezinkalbine- $\%$ E2\%80\%98Kent-Meydani)

Kepez Kent Meydanı, çok amaçlı etkinlik alanı, konserler, söyleşiler, sergiler, mitingler gibi aktivitelerin gerçekleşmesine olanak sağlayacak şekilde tasarlanmış, yoğun olarak dört mevsim yaşayabilen endemik bitkilerin yer aldığı peyzaj alanları da oluşturulması planlanmıştır. Meydan; çiçeklikler, banklar, asmagerme sistemler, alçak ve yüksek boylu aydınlatma birimleri, çöpler, döküm ağaç koruyucular ve membran gölgeleme alanları, geçici ve kalııı yapısal hacimler gibi estetik değeri olan donatılarla desteklenmektedir. Ancak, çevredeki konut bloklarının meydanın fonksiyonuna olumsuz etkisi soru işareti oluşturmaktadır. 


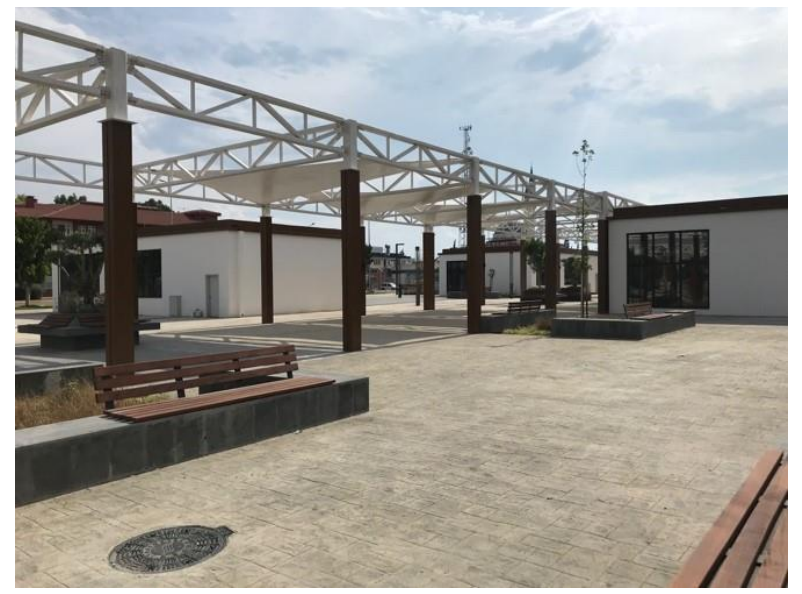

Şekil 10. Kepez Kent Meydanı Gölgeleme Elemanları ve Kalıcı Yapısal Elemanlar

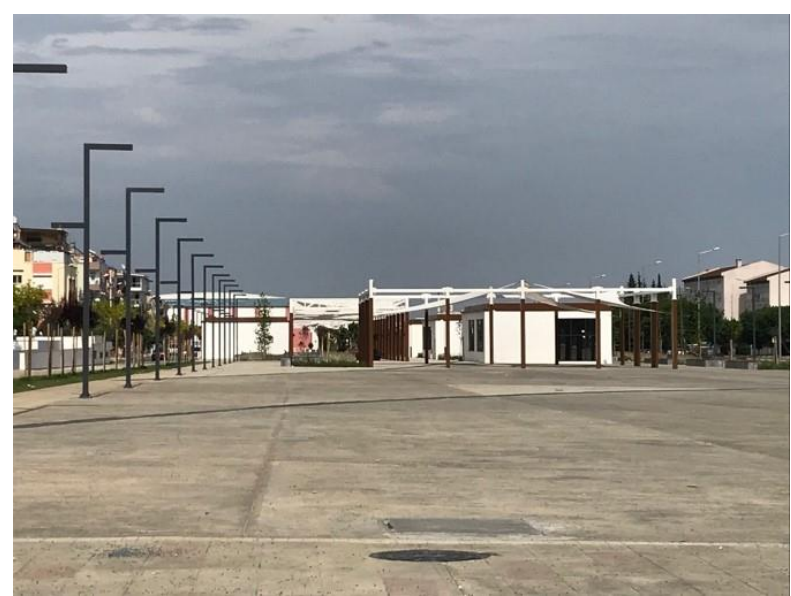

Şekil 11: Kepez Kent Meydanı Asma-Germe Sistemler

Kepez Kent Meydanı, kent ölçeğinde değerlendirildiğinde belediye sınırları içerisinde bir anlam ifade edebilecekken, kent ölçeğinde bir 'yer'e dönüşmesi olası görülmemektedir. Bunun sebepleri arasında kapalılık hissinin zayıflı̆̆ 1 , kentten diğer meydanlara nazaran uzak kalması gösterilebilir. Belediye sınırlarının merkezinde bulunması dolayısıyla, kolay ulaşılabilirlikle beraber bireylerin hafızasında ve anılarında da kolayca yer edinmesi beklenmektedir. Bu bağlamda, Kepez sakinlerinin kent meydanına gitmesi, hafizalarında anılar biriktirmesi, birey ölçeğinde kendilerine bir 'yer' edinmeleri olası görülmektedir. Ancak, kent ve birey ölçeğinde olumlu olarak görülen bu planlama için; yapım aşamasında planlı, kaliteli ve olumlu bir inşa süreci oldukça önemli rol oynamaktadır.

\subsection{Konyaaltı Kent Meydanı}

Antalya'nın son yıllarda aldığı aşırı göç sonrası, aşırı yapılaşma ve planlama gereksinimlerinden Konyaaltı ilçe sınırları da etkilenmiştir. Kent, gelen aşırı göç sonrası batıya doğru hızla gelişmiştir. Konyaaltı kentsel alanları ve meydanları da, Antalya kentinin gelişim ve değişim sürecinin çarpıcı şekilde mekâna yansıdığı bir bölgedir. Son on yılda yoğun yerleşimin var olduğu ilçe, öncesinde yazlık ve/veya ikinci konutların konumlandığı, sonrasında ise yerel nüfusunda yerleştiği ve kentsel gelişimin görece planlı olarak devam ettiği bir özelliktedir.

Konyaaltı sahil şeridinde konumlanan 54.750 m2 büyüklüğündeki Konyaaltı Kent Meydanı Konyaaltı Belediyesi sınırları içinde bulunmaktadır ve Konyaaltı sahilinde yapılaşmadan kalan alanlardan birisidir. Mimarlar Odası'nın önerisi üzerine Konyaaltı Belediyesi kent meydanı olarak ayrılan kısmın düzenlenmesi için fikir projesi yarışması açmıştır. 11.11.2004 tarihinde ulusal ve tek aşamalı olarak açılan Kent Meydanı Fikir Proje Yarışması 31.01.2005 tarihinde sonuçlanmıştır ve proje bazı yapısal değişikliklere uğrasa da uygulanmıştır. 


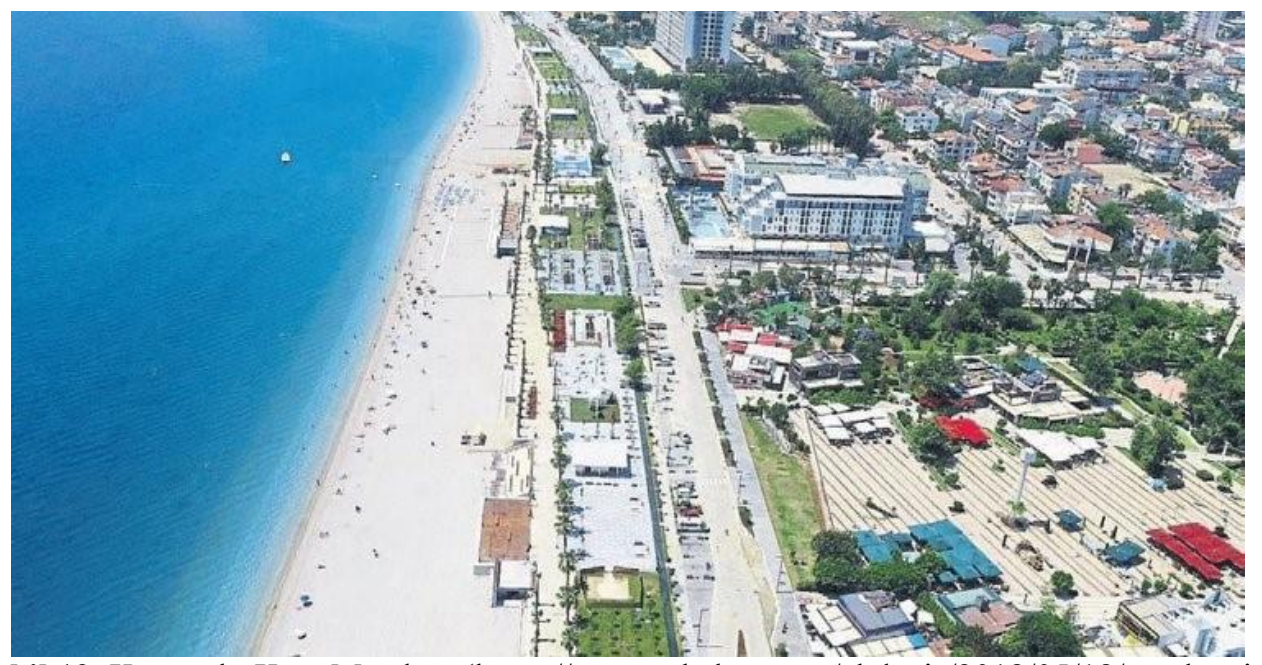

Şekil 12. Konyaaltı Kent Meydanı (https://www.sabah.com.tr/akdeniz/2018/05/18/antalyaningerdanligi)

Konyaaltı Kent Meydanı, yarışmayı kazanan müellifler tarafından şu şekilde aktarılmıştır : Akdeniz'den referans alarak oluşan meydan, meydanı biçimleyen ve yaşatan, yaşama sevincini kamçılayan yaşam ve sanat aksları, aynı mimari dille meydandan çıkan rekreatif faaliyetlerin çeşitliliğini zenginleştiren aktivite aksı tasarımın temel unsurlarıdır. Kapalı alan olarak sadece 0.0088 emsal ile max. h: 5.50 yüksekliğinde 600 metrekare olarak tasarlanan projede 3 büfe, 3 kafe, satış birimi, çok amaçlı yap1 ve restoran bulunmaktadır. Meydanın kuzeyinde 80 araçlık, batısında ise 25 araçlık açık otopark ve çocuk oyun alanı düzenlemesi yapılmıştır. (Esengil 2010)

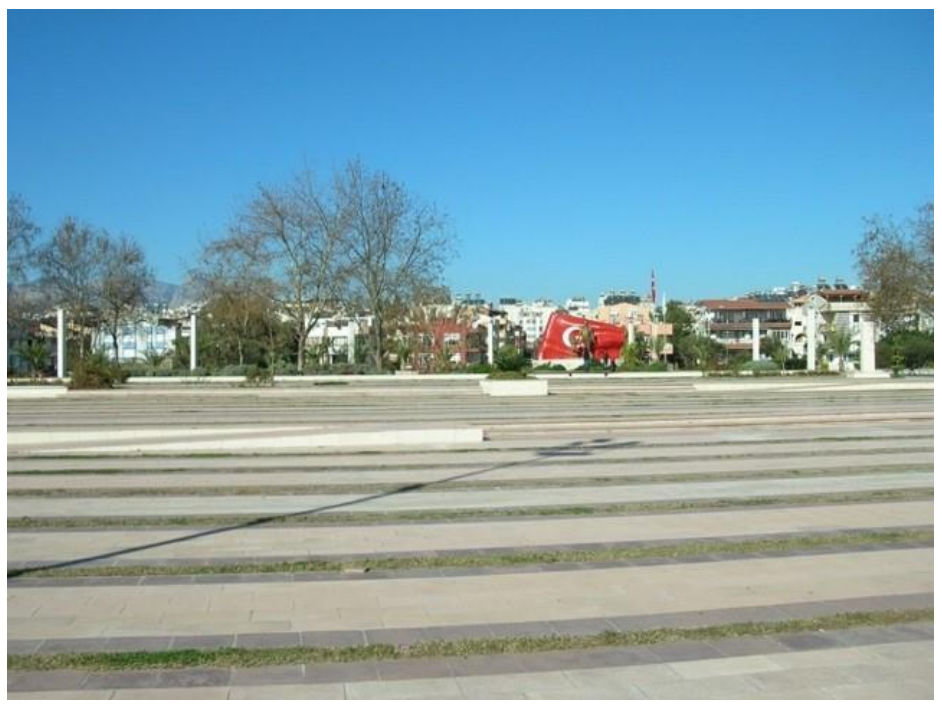

Şekil 13. Konyaaltı Kent Meydanı ve Atatürk Büstü

Konyaaltı Kent Meydanı, günümüzde farklı yaş ve cinsiyetteki bireyler tarafindan aktif bir şekilde kullanılmaktadır. Günün her saatinde başka bir hareketin gözlemlenebildiği meydan, kullanım olarak bireylerin yanı sıra kente hizmet eden bir hale gelmiștir. Kent ölçeğinde incelendiğinde, Antalya'daki bir bireyin zihninde yer edinmiştir ve kentsel simgelerden birisi haline gelmiştir. Birey ölçeğinde düşünüldüğünde ise, ilk başlarda sadece resmi törenlerin yapıldığı bir alanken, zamanla anıların biriktirildiği, aidiyet hissedilen, buluşma noktası olmuş bir 'yer'e evrildiği olduğu söylenebilir. Gölgeleyici nitelikteki peyzaj düzenlemelerinin yetersiz oluşu meydanın kullanımını olumsuz yönde etkilese de meydanın çeperlerinde açık ve yarı açık kullanımı destekleyen işlevlerin yoğunlaşması meydanın yaşamasını desteklemektedir. Bu özellikleri dolayısıyla Konyaaltı Kent Meydanı hem kent ölçeğinde, hem birey ölçeğinde bir "yer" oluşturma sürecindedir. 


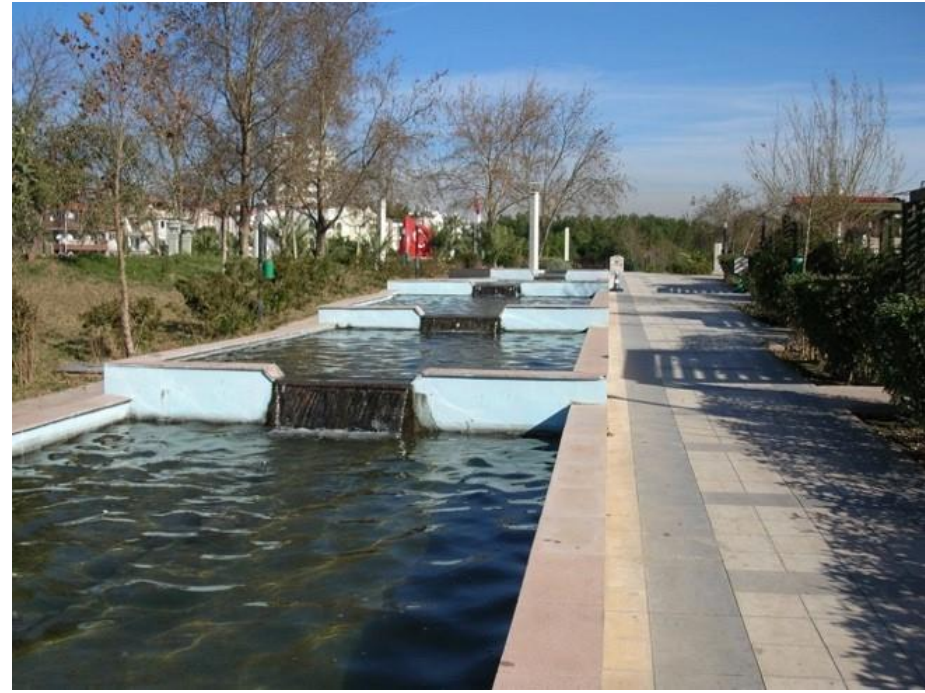

Şekil 14. Konyaaltı Kent Meydanı ve Kotlu Havuz Tasarımı

\subsection{Muratpaşa Kent Meydanı}

Kentin en eski yerleşim yeri olması nedeniyle Muratpaşa'nın tarihi aynı zamanda Antalya'nın da tarihidir. Tarihi Kaleiçi Bölgesi’ni içerisinde barındıran sınırları, zamanla doğuya doğru genişleyerek günümüzdeki sınırlarına ulaşmıştır. Son yıllarda aldığı göç ile tıpkı diğer belediye sınırları gibi hızla genişlemiş ve günümüzde 8 bin 804 hektarlık alana sahiptir. 20 kilometre sahil kıyı bandı bulunan Muratpaşa' nın güneyinde Akdeniz, kuzeyinde Kepez ilçesi, batısında Konyaaltı, doğusunda da Aksu yer almaktadır. 1993 yılında Büyükşehir Belediyesi'nden ayrılan belediye, daha sonra kent merkezinin yaklaşı $7 \mathrm{~km}$ doğusundaki Lara bölgesinde yeni belediye hizmet binası inşaatının tamamlanmasıyla buraya taşınmıştır.

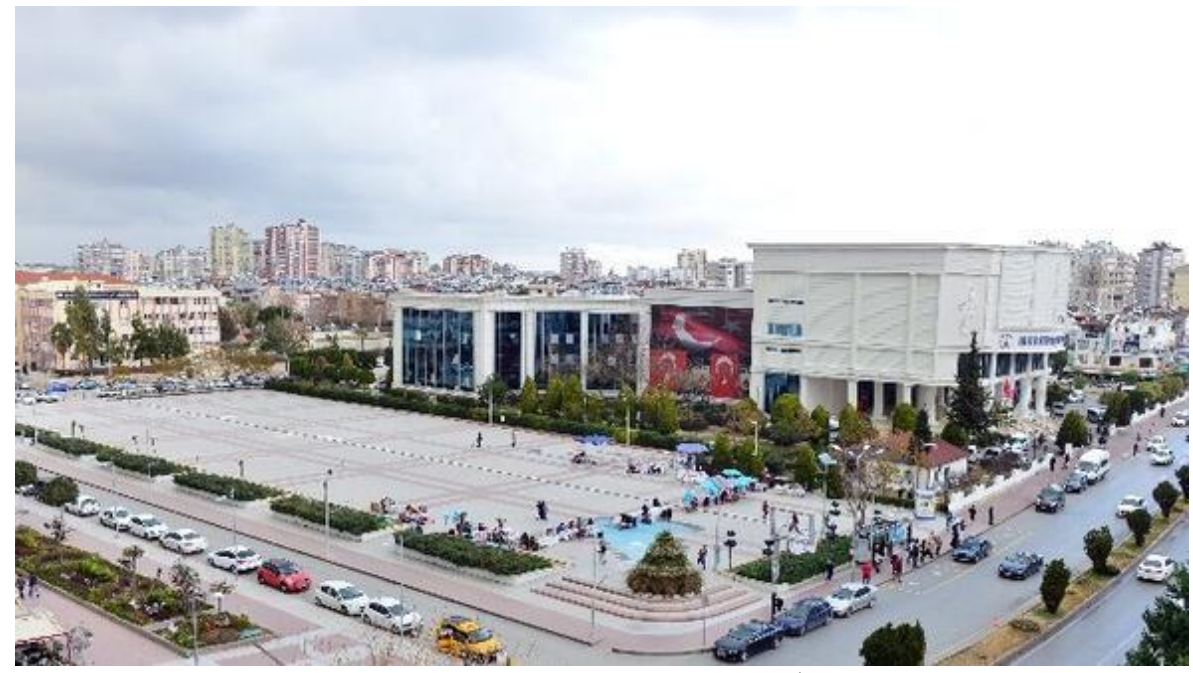

Şekil 15. Muratpaşa Kent Meydanı

Muratpaşa Kent Meydanı, Muratpaşa Belediyesi hizmet binasının batı kısmında, $6.250 \mathrm{~m} 2$ alan üzerinde gerçekleştirilen sert zemin uygulamasının sonucudur. Batı kısmında Antalya kent merkezindeki büyük AVM'lerden biri, kuzeyinde konut dokusu, güneyinde Tekelioğlu Caddesi ve konut dokusu bulunmaktadır. Sadece bir kentsel boşluk olarak düşünülmüş ve bu doğrultuda sert zemin kaplaması ile sonlandırılmış bir açık alan olma özelliği taşıyan Muratpaşa Kent Meydanı, herhangi bir gölge elemanı yardımı ile gölgelenmemekte, yeşil alanların eksikliği göze çarpmakta, kent mobilyalarının eksiliği hissedilmektedir. 


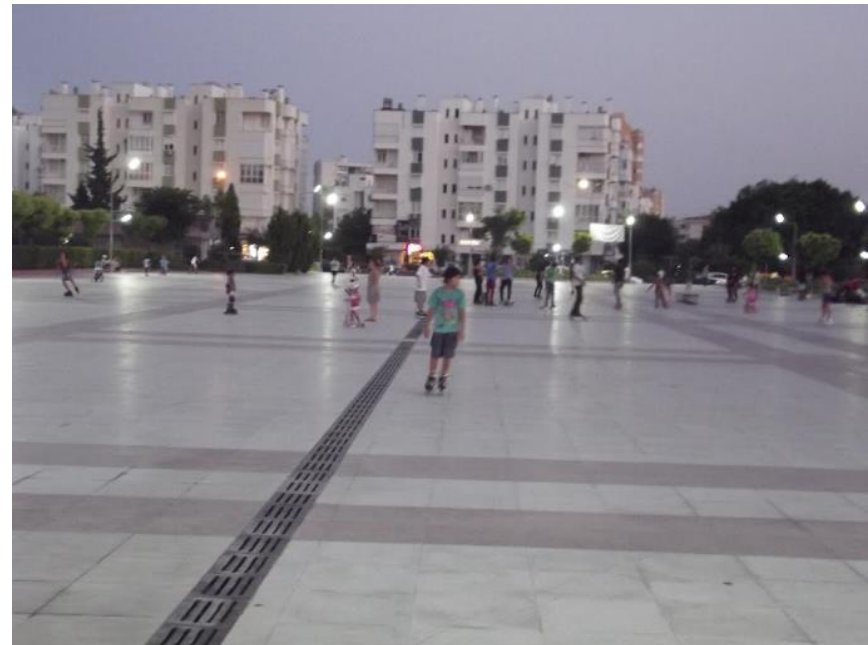

Şekil 16. Muratpaşa Kent Meydanı Sert Zemin Kaplaması

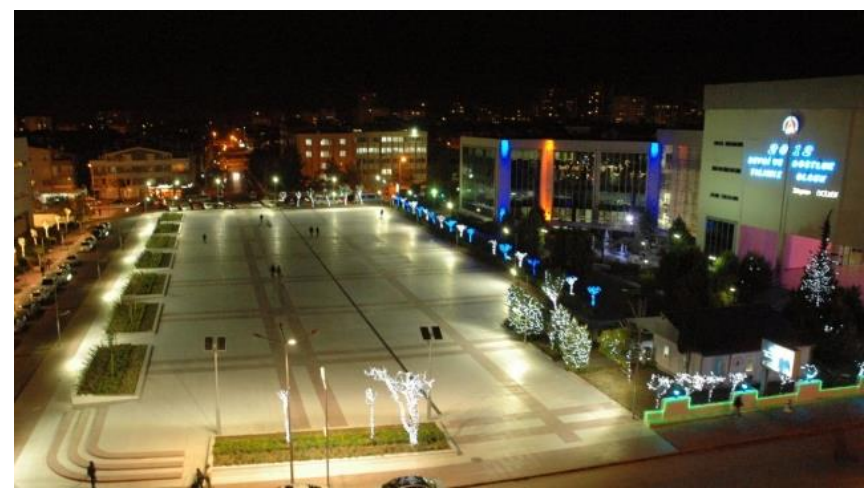

Şekil 17. Muratpaşa Kent Meydanı Gece Görüntüsü

Söz konusu açık alanın doğu ve batı çeperleri insan ölçeğine yabancı, yarı-açık ve açık mekan kullanımları ile meydanı beslemeyen iki yapı ile tarif edilmiştir. Doğu kısmında belediye hizmet binası, batı kısmında AVM bulunmaktadır. Tarihsel gelişimi itibarı ile "yok-yer" niteliğindeki bir yapı tipinin temsilcisi olan AVM bloğunun konumlandırılması meydan kavramının ilk hedefi olan 'yer' niteliğinden uzaklaşarak, 'yok-yer'e evrilmesini desteklemiştir. AVM halihazırda oldukça dışa kapalı, bireyin anonimleştiği, aidiyet duygusunu kaybettiği ve kendi içinde yok-yer olma özelliğini barındıran bir yapıdır. Dolayısıyla Muratpaşa Kent Meydanı, doğudan ve batıdan beslenmeyen çeperlerle çevrelenmiştir. Kent ölçeğinde değerlendirildiğinde, kentli aidiyeti açısından herhangi bir katkısı olmayan mekân, birey ölçeğinde ise belediyeye veya alışveriş merkezine ulaşımı sağlayan bir yaya dolaşım aksı, bir sert zemin olarak kullanılmaktadır. Kent hafızaya katkı sağlayamaması, deneyimleyen bireylerde ayırt edici bir anı bırakmaması ve dolayısıyla aidiyet hissinin üretilememesi bakımından bu meydan denemesi hem kent ölçeğinde, hem birey ölçeğinde "yer" üretimini geliştirme potansiyeline sahip değildir. Dolayısıyla bu örneğin 'yok-yer' niteliğine daha yakın olduğu değerlendirilebilir.

\section{Değerlendirme ve Sonuç}

Kent ve toplum kimliğinin oluşumunda önemli işlevi olan kent meydanları, günümüz koşullarında çoğu örnekte içerisinde bulundurması gereken özelliklerden uzak, aidiyet hissi uyandırmayan, bireyin anonimleştiği birer geçiş mekanlarına dönüşmektedirler. Ancak zamanla işlevlerini yitirip, kimlik arayışı içerisine girmiş ve genel nitelikleri “yer”den "yok-yere” evrilmeye başlamıştır.

Oysa meydanlar; insanlar için bir tür yaşamı paylaşma mekanı olmalıdır. Bir meydanın canlılığına meydandaki insan sayısından çok, kullanıcı grubu için; mekanda kaliteli vakit geçirebilme, görsel kalite, konfor, fonksiyonların çeşitliliği, boş zamanlarını değerlendirebilecekleri, sıkılmayacakları, kentlilik bilincini ve kentsel kültürü destekleyen aktivitelerden oluşan alanların yer alması önemlidir. Böylece, kentsel yaşamın canlandırılması da söz konusu olacaktır. Bu canlanma ile birlikte kentsel anılar çoğalacak, aidiyet hissi kuvvetlenecek ve kentsel meydan tekrar bir "yer" olmaya başlayacaktır.

Kent meydanlarının yok-yerlere evrilmesi durumunu iyi analiz edebilmek için, bu çalışmada problem 
kent ölçeğinde ve birey ölçeğinde olmak üzere iki ana başlıkta incelenmiştir. Farklı kombinasyonları barındırması bakımından Antalya ili seçilmiş ve bu bağlamda seçilen kent meydanlarının analizleri sonucunda aşağıdaki sonuçlara ulaşılmıştır.

Cumhuriyet Meydanı, kent için ilk meydan olması özelliğinin yanı sıra, her zaman simgesel özelliğini korumuş, kent ölçeğinde incelendiğinde 'yer' olan meydan, birey ölçeğinde de kentte yaşayan insanlara aidiyet hissi vermesi, estetik değeri olan çevresel donatılarla desteklenmesi ve kentliler için anlam taşıması bakımından da bir 'yer' olarak değerlendirilebilir.

Kepez Kent Meydanı, kent ölçeğinde değerlendirildiğinde belediye sınırları içerisinde bir anlam ifade edebilecekken, kent ölçeğinde bir 'yer'e dönüşmesi olası görülmemektedir. Bunun sebepleri arasında kapalılık hissinin zayıflığı, kentten diğer meydanlara nazaran uzak kalması gösterilebilir. Belediye sınırlarının merkezinde bulunması dolayısıyla, kolay ulaşılabilirlikle beraber bireylerin hafizasında ve anılarında da kolayca yer edinmesi beklenmektedir. Bu bağlamda, Kepez sakinlerinin kent meydanına gitmesi, hafizalarında anılar biriktirmesi, birey ölçeğinde kendilerine bir 'yer' edinmeleri olası görülmektedir.

Konyaaltı Kent Meydanı, kent ölçeğinde incelendiğinde, zamanla Antalya'da yaşayan bireylerin zihninde yer edinmiştir ve kentsel simgelerden birisi haline gelmiştir. Birey ölçeğinde düşünüldügünde ise, ilk başlarda sadece resmi törenlerin yapıldığ 1 bir alanken, zamanla anıların biriktirildiği, aidiyet hissedilen, buluşma noktası olmuş bir 'yer'e doğru evrilme potansiyelini taşıdığı söylenebilir. Bu bağlamda, Konyaaltı Kent Meydanı için hem kent ölçeğinde, hem birey ölçeğinde 'yer' niteliği söz konusudur.

Muratpaşa Kent Meydanı'nın ise, kent ölçeğinde değerlendirildiğinde, kente özgü mekânsal deneyim imkanı sunamaması dolayısıyla kentlilik bilinci oluşmasına belirgin bir katkısının olmadığı, birey ölçeğinde ise belediyeye veya alışveriş merkezine ulaşımı sağlayan bir yaya dolaşım aksı, bir sert zemin olma durumunu aşamadığı görülmektedir. Bu örnek, günümüzdeki durumu çerçevesinde, kent ölçeğinde bir hafiza yaratamaması, meydanı deneyimleyen bireylerde kente özgü bir anı bırakmaktan uzak oluşu ve aidiyet hissi oluşturamaması bakımından hem kent ölçeğinde, hem birey ölçeğinde "yok-yer" niteliğine daha yakın bir konumda görülmektedir.

Kentsel bir meydanın, fiziksel özelliklerinin yanısıra toplumsal, sosyolojik, psikolojik anlamlarıyla bir bütün olarak ele alınması gerekmektedir. Çoğu zaman sadece kentteki bir boşluk, geçiş alanı veya resmi tören alanı olarak görülen meydanların kentsel nitelikleri "yok-yer" tanımına giderek daha fazla yaklaşmaktadır. Oysa meydanlar kentsel yaşamın canlılığını destekleyen, kentli için aidiyet hissinin oluşmasını sağlayan kentli odaklı bir tasarım ve uygulama yaklaşımıyla yorumlanmalı ve değerlendirilmelidirler.

\section{Kaynaklar}

Alexander, C., Ishikawa, S., Silverstein, M., Jacobson, M., Fiksdahl-King, I. ve Angel, S. (1977). A pattern language:towns, buildings, construction. New York:Oxford University Press.

Augé, M. (2016) Yok-yerler Üstmodernliğin Antropolojisine Giriş, Daimon, İstanbul.

Aykurt, A.S. 2010. Planlama Ve Uygulama Süreçlerinde Kent Meydanları: Antalya Cumhuriyet Ve Konyaaltı Kent Meydanlarında Karşılaştırmalı Bir Araştırma, Akdeniz Üniversitesi.

Casey E., The Fate of Place: A Philosophical History, University of California Press, Berkeley, 1997, s. 135.

Esengil Z., Planlama ve Tasarım Sürecine Katılımın Kamusal Projeler Bağlamında İrdelenmesi: Antalya Kent Merkezi Örneği, İTÜ, Yüksek Lisans Tezi, İstanbul.

Erdönmez, M.,E., Akı, A., (2005), “Açık Kamusal Kent Mekanlarının Toplum İlişkilerindeki Yeri”, Megaron YTU Mim. Fak. E-Dergisi, Cilt 1, Sayı 1, İstanbul.

Gehl, J., 2011. Life Between Buildings: Using Public Space. Island Press, USA.

Giddens A., Modernliğin Sonuçları, çev. Ersin Kuşdil, Ayrıntı Yayınları, İstanbul, 2004, s. 26. 
Giritlioğlu, C., 1991. Şehirsel Mekan Öğeleri ve Tasa- rımı. İTÜ Mimarlık Fakültesi Yayını, İstanbul.

Fauole, P ., 1995. Squares in Contemporary Architecture. Waanders Publishers Architectura \& Natura Press, Amsterdam.

Krier, R., 1979. Urban Space. Rizolli Int. Publications Inc., New York.

Kuntay, O., 1994. Yaya Mekanı. Ayıntap Yayıncılık, Ankara.

Lynch K., 2011, Kent İmgesi, Türkiye İş Bankası Kültür Yayınları, İstanbul.

Marcus, C. C., Francis, C., 1998. People Places 'Design Guidelines for Urban Open Space'. Van Nostrand Reinhold Company, New York.

Norberg-Schulz, C., 1980. "Genius Loci: Towards a Phenomenology of Architecture”, New York, Rizzoli.

Norberg-Schulz C., The Concept of Dwelling, Rizzoli Publications, New York, 1993, s. 51.

Schulz-Norberg, C., 1971. Existence, Space and Architecture, London: Studio Vista, London.

Sharr, A. Mimarlar için Heidegger, YEM yayın, İstanbul, 2010, s.10.

Önder, S., Aklanoğlu, F., "Kentsel Açık Mekan Olarak Meydanların İrdelenmesi" S. Ü. Ziraat Fakültesi Dergisi 16 (29): (2002) 96-106

Ötkünç A. (2016). “Antropolojiden Mimarlığa Melez Düşüncenin İmkanları: Yer ve Yok-yer Kavramları Üzerine”, Yok-yerler. Marc A., Daimon Yayınları, İstanbul, s.7-29.

Öztan, Y., 1998. Kentler ve Meydanlar. Maison Française Dergisi, No:33, 154-157, İstanbul.

Uzun, G., 1990. Kentsel Rekreasyon Alan Planlaması. Ç.Ü. Ziraat Fakültesi Ders Kitabı, Yayın No:48, Adana.

Zucker, P. 1959: Town and Square. Columbia University Press. Newyork. 